\title{
Using reflection triggers while learning in an online course
}

Citation for published version (APA):

Verpoorten, D., Westera, W., \& Specht, M. (2012). Using reflection triggers while learning in an online course. British Journal of Educational Technology, 43(6), 1030-1040. https://doi.org/10.1111/j.1467-8535.2011.01257.x

DOI:

10.1111/j.1467-8535.2011.01257.x

Document status and date:

Published: 21/11/2012

Document Version:

Early version, also known as pre-print

\section{Document license:}

CC BY

Please check the document version of this publication:

- A submitted manuscript is the version of the article upon submission and before peer-review. There can be important differences between the submitted version and the official published version of record. People interested in the research are advised to contact the author for the final version of the publication, or visit the DOI to the publisher's website.

- The final author version and the galley proof are versions of the publication after peer review.

- The final published version features the final layout of the paper including the volume, issue and page numbers.

Link to publication

\section{General rights}

Copyright and moral rights for the publications made accessible in the public portal are retained by the authors and/or other copyright owners and it is a condition of accessing publications that users recognise and abide by the legal requirements associated with these rights.

- Users may download and print one copy of any publication from the public portal for the purpose of private study or research.

- You may not further distribute the material or use it for any profit-making activity or commercial gain

- You may freely distribute the URL identifying the publication in the public portal.

If the publication is distributed under the terms of Article 25fa of the Dutch Copyright Act, indicated by the "Taverne" license above, please follow below link for the End User Agreement:

https://www.ou.nl/taverne-agreement

Take down policy

If you believe that this document breaches copyright please contact us at:

pure-support@ou.nl

providing details and we will investigate your claim.

Downloaded from https://research.ou.nl/ on date: 26 Apr. 2023 
THIS IS A PRE-PRINT OF: Verpoorten, D., Westera, W., \& Specht, M. (2011c). Using reflection triggers while learning in an online course. British Journal of Educational Technology, 43(6), 1030-1040. DOI: 10.1111/j.1467-8535.2011.01257.x.

\section{Using reflection triggers while learning in an online course}

\section{Dominique Verpoorten, Wim Westera and Marcus Specht}

The authors work with the Centre for Learning Sciences and Technologies (CELSTEC) of the Open Universiteit Nederland. The study takes place in a research program dedicated to prompts and interface for meta-learning support, in regular, adaptive and mobile eLearning. Address for correspondence: Dominique Verpoorten, CELSTEC, Open University in the Netherlands, PO Box 2960, 6401 DL Heerlen, The Netherlands. Email: dve@ou.nl

\section{Abstract}

This paper reports about a controlled experiment on the effects of three types of reflection triggers in an online course. 54 volunteers, distributed in 5 groups, used these structured opportunities for reflection during learning. Results show that reflection triggers were extensively employed by the test persons and were perceived as quite useful to reflection and learning. Test persons in the experimental groups reported significantly more reflective prompting and more intensive reflection than those in the control group. In contrast, no positive effects on learner performance and retention could be established. This paradox elicits different possible explanations which are discussed in the light of the common pedagogical claim that more thoughtful approaches to learning should be promoted.

\section{Structured practitioner notes}

What is already known about this topic

- For many years, both teachers, researchers and prominent authors (Schön, Bateson, Kolb) have been stressing the importance of reflection for learning, both in regular classrooms and in eLearning settings.

- Reflection can aim at enhancing the effectiveness of learning and/or promoting metacognition or similar notions like "learning to learn" or "self-regulation", all considered as essential skills for knowledge workers.

- Today's electronic learning environments expand opportunities to reinforce reflection by prompting learners about the content at hand and about own ways of internalizing it.

What this paper adds

- Although a wide variety of reflection triggers can be observed in the literature, there is only little and scattered research evidence available about the assumed effects and usage. This paper addresses this lack of empirical data by surveying 3 concrete and structured reflection affordances.

- The promotion of reflection is nowadays often associated to post-practice reflective tools like portfolio or learning diary. This paper brings in the forefront a different type of tool that targets reflection in action.

- This paper relates its findings to similar experiments and pending questions in order to offer a context for the discussion about compact and cost-effective ways to stimulate reflection while learning.

Implications for practice and/or policy 
- Some institutions are experimenting with efforts to teach more than how to pass exams: they are looking for ways to enhance their students' meta-cognition. This study explores the provision of reflection triggers as one possibility to make learning processes and habits (good or bad) more tangible.

- Teachers might feel they lack time to promote meta-cognition. However, the reflection triggers suggested in this article might amount to very short periods of time. This costeffective approach might allow to avoid "sacrificing" content or burdening educators and learners.

- The article invites teachers to evaluate against their audience and learning goals the relevance of giving a face value to reflection instead of assuming that this reflection will occur. If they would then decide to use reflection triggers, the article offers ideas for innovative crisscrossing between cognitive and meta-cognitive landscapes in online formal learning settings. It also elaborates on the observed limitations of the approach.

\section{Introduction}

Meta-analysis (Hattie, 2008; Marzano, 1998) or literature reviews (Watkins, 2001) repeatedly pinpoint reflective practice as a highly influential factor in learning, if not the most influential one (Wang, Haertel, \& Walberg, 1990). It is generally acknowledged that stimulating reflective skills will prepare knowledge workers to cope with requests for new knowledge acquisition and ongoing personal development in the information society (European Commission, 2006). Today's electronic learning environments offer new opportunities for reinforcing reflection, especially in self-instructed contexts, that is situations wherein learners cannot rely upon an instructor to directly inform and stimulate their thinking about learning contents and processes. This paper describes a controlled comparative experiment about the use of "reflection triggers" in such a mode of learning.

\section{Reflection triggers}

"Reflection triggers" (RTs) refer to deliberate prompting approaches that offer learners structured opportunities to examine and evaluate their own learning (Verpoorten, Westera, \& Specht, 2010). Whereas the promotion of reflection is often associated with post-practice methods of experience recapture (Boud, Keogh, \& Walker, 1985) through portfolios or learning diaries (Moon, 1999) or with the use of dialogue and collaborative activities as levers of thinking (Brockbank \& McGill, 1998), RTs are nested in the study material and offered to individuals during learning activities. They induce regular mental tingling for evaluating one's own learning and nurturing internal feedback (Butler \& Winne, 1995). In the temporal flow of learning, their contiguity to student's doings commits RTs to reflection-in-action more than to reflection-on-action, though Schön's (1983) famous distinction is relative: even a reflection that takes place "in action" bears on a pre-existing context but, in the case of a RT, the interval is a matter of seconds. The concise reflection which they call for further characterizes RT. To support condensed reflective processes, RTs operate though miniature Web applications (sometimes called "widgets") performing a single task, displaying a very clear and appropriate graphical style and providing a single interaction point for direct visualization or provision of a given kind of data (Verpoorten, Westera, \& Specht, 2011). The application of such compact opportunities for reflection touches on a principal question though: is the very idea of a "short" reflection a contradiction or can embedded reflection be brief and valuable at the same time? Beyond theory, there is a practical stake in this question: teachers as well as learners may be reluctant to reflective approaches, since these are supposed to happen at the expense of studying course contents. It is a major challenge to establish reflective learning practices without swamping the time available. 


\section{Research questions}

Two main questions guided the experiment: a) do RTs embedded in a study task engage learners in active reflection?, b) does this reflection positively affect the performance? Two secondary research questions were tackled: a) do multiple RTs have a greater effect than one single RT?, b) is there any observable difference of effects between the types of RTs used? Lastly, the study collected learners' perception and appreciation of RTs and confronted these qualitative outcomes with performance data.

\section{Methodology}

In a comparative study an online course was delivered at 5 different conditions. The intervention variables were the exposure to reflection triggers (different numbers, different types). The dependent variables were performance, time spent on the course and participants' perceptions of RTs.

\section{The online course}

The two-hour online course "Web usability principles" was created for the occasion on the eLearning platform Moodle. It provided reading material on 20 pages that participants could freely navigate. A final test assessed the content mastery reached by the learner.

\section{Three types of reflection triggers}

The study exposed participants to RTs selected from the inventory proposed by Verpoorten, Westera, and Specht (2010). This work classifies reflective techniques according to 3 distinctive types of actions requested from the learners to enact reflection: type 1) receiving information, type 2) giving information, type 3) verbalizing information. Consistently with its comparative purpose, the study used one RT selected in each category. In the introductory section of the course, the offered RTs were explained and described as "support to reflection and appreciation of one's position within the learning process". Their use was stated as compulsory, as part of an effort to be as close as possible of a formal learning activity system, which is usually organized around a curriculum (closed corpus), is teacher-controlled, and offers compelling tasks with predefined learning resources. For tracking purpose, students had to deliberately activate the RTs. When learners were about to leave a page without having used RTs, a reminder pop-up enacted.

RT 1 - Compare with yardstick

This RT of type 1 offers learners an opportunity to compare aspects of their learning experience to some external yardstick (teacher, peer, expert, classroom average, oneself in similar circumstances, compliance ratio, etc.). A yardstick relates an individual performance to a larger context (Glahn, Specht, \& Koper, 2007). In this study, learners could compare the number of actions they performed so far with a static yardstick: the number of actions performed by a previous group of peers (Figure 1). Such real-time mirroring of personal tracked data is assumed to encourage a more thoughtful monitoring and calibration of actions.

\section{$<$ INSERT FIGURE $1>$}

RT 2 - Rate your mastery of this page

This is a type 2 RT ("giving information/ responding"). It induces the reflective experience by asking learners to give a quick insight into their behaviours or performances through the use of a rating scale. On each page visit or revisit participants rated their perceived mastery level of the page content by selecting the appropriate number of stars (Figure 2a). For each level a 
standardized explanation was given. In case of multiple visits the history (Figure $2 b$ ) of this self-reported measure was available and steadily built a progress track.

\section{$<$ INSERT FIGURE 2>}

RT 3 - Write on the content

This RT is of type 3 ("verbalizing information"): it aims for inducing a reflective experience by asking the learners to produce a mental or written discourse about certain aspects of their learning. The online course offered the RT as a comment box available on each page. Whenever learners left a page, they first had to enter an annotation.

\section{Sample and schedule}

Early in 2010, invitations to participate in a 3-hour experiment were displayed in 4 Linked'in discussion groups and spread in institutions from the authors' institutional network. 92 volunteers were randomly distributed over the 5 conditions: no RT, all RTs, RT1 (yardstick), RT2 (rating tool), RT3 (comment box). After the completion of a 20' background questionnaire, the subjects received the Web address of the course version matching their treatment. They had one month to complete it, take the final test and answer the 20' postquestionnaire right after. Group 5 - "comment box" condition - suffered from a high proportion of drop-outs (questioned in the "Discussion" section). Despite its inadequate size, this group was included anyway because of the importance of qualitative data. The attrition rate was stable across the other groups. Table 1 gives a compact view of the treatments and their usable samples. The 54 subjects who completed the experiment received a certificate for participation and a reward.

\section{$<$ INSERT TABLE $1>$}

\section{Measure instruments}

The data sources for this study were the returns from the questionnaires, the tests and the analyses of logs.

\section{Background questionnaire}

Reflective skills and similar notions such as meta-cognitive capacity were critical with regard to reflection triggers. In order to obtain learners characteristics regarding these skills, 3 instruments were included in the background questionnaire: the Mindful Attention Awareness Scale (Brown \& Ryan, 2003), the Need For Cognition Form (Cacioppo \& Petty, 1982) and the Meta-cognitive Awareness Inventory (Schraw \& Dennison, 1994). Self-reported level of mastery in the domain and familiarity with ICT were also collected.

\section{Short and long-term performance}

A test taken straight after the study session measured learners' achievement. This performance test a) was on-demand and taken when the students felt that they had achieved the highest possible level of content mastery, b) could be taken only once, c) had a time limit so that the reflection took place while covering the material and not at the moment of the test, d) could be anticipated by the participants through examples of test questions, e) blocked access to the electronic material once launched, f) combined 5 "verbatim", 5 "comprehension inference" and 1 final integrative "knowledge inference" questions, the last two types of questions requesting deep understanding of the material (Chi, De Leeuw, Chiu, \& Lavancher, 1994). Six weeks after the first test, participants answered a shorter version thereof to capture retention. By this time, they no longer could access the course. 


\section{Behavioural metrics}

Log files of online sessions yielded different usage patterns: a) total time spent on course, $b$ ) number of pages (re-)visited, c) use of RTs, d) time spent on the final test.

\section{Feedback from learners}

A second online survey, taken right after the final test, provided participants' feedback on RTs. The questionnaire comprised:

1. judgments on the levers and the intensity of reflection in the course, measured by the "Reflective Thinking" scale of the COLLES questionnaire (Taylor \& Maor, 2000) that generates a measure of students' perceptions about a course;

2. opinions on the RT: weak and strong points, contribution to learning, learners' intentions of reuse.

\section{Results}

The presentation of the results is mapped onto the structure of the above section "Measure instruments". An alpha level of .05 was used for all statistical tests.

\section{Background questionnaire}

To ensure equivalence between groups at baseline, one-way ANOVAs were performed on the 3 meta-cognitive skills questionnaires and exhibited samples equivalence: MAAS: $F(4,49)=$ $0.16, p=.95, \eta \mathrm{p} 2=.137, \mathrm{NFC}: F(4,49)=0.53, p=.70, \eta \mathrm{p} 2=.0003$, MAI: $F(4,49)=0.65, p$ $=.62, \eta \mathrm{p} 2=.027$. The measures of initial self-reported familiarity with eLearning and selfreported knowledge about the domain also indicated comparable groups. Besides this even distribution, the background questionnaire revealed the high meta-cognitive agility of the sample. Only 4 volunteers with a lower profile enrolled in the experiment, allowing an enrichment of the observations by providing some contrast regarding usage and perceptions of the RTs.

\section{Short and long-term performance}

Despite mean scores looking substantially higher for the control group (Table 2), a one-way ANOVA communicated that differences were not significant, neither for the final test $\mathrm{F}(4,49)$ $=0.28, \mathrm{p}=.89, \eta \mathrm{p} 2=.022$, nor for the retention test, $\mathrm{F}(4,49)=0.31, \mathrm{p}=.86, \eta \mathrm{p} 2=.11$.

\section{$<$ INSERT TABLE 2>}

\section{Behavioural metrics}

The processing of this data yielded the following observations:

- RTs were used as requested;

- RTs did not influence the time spent on the study phase, ANOVA: $F(4,49)=0.29, p=$ $.87, \eta_{\mathrm{p} 2}=.023$.

- RTs did not impact the time spent on the test, ANOVA: $F(4,49)=0.31, p=.86, \eta_{\mathrm{p} 2}=$ .008 .

- loops between low self-ratings of mastery and further access to insufficiently mastered pages did not show up. The attention to learning brought by the RTs did not translate into concrete monitoring actions.

\section{Feedback from learners}

Learners' perspective on RTs is collected in 5 dimensions: reflection triggered, contribution to learning, intention of reuse, appreciation and awareness. 
Perceived intensity of reflection

To what extent did learners report any reflection during the course, no matter what this reflection was exactly about and how it might be triggered? Calculations based on the "Reflective Thinking" Likert scale of the COLLES questionnaire revealed that relative frequencies for the items "I often reflect" or "I almost always reflect" were significantly lower in the control group than in the aggregated treatment groups, $\chi^{2}(4, \mathrm{~N}=54)=11.444, p$ $=.022$. Significant differences were confirmed by separate chi-square tests. In sum, 3 treatment groups out of 4 (exception is RT3, group 5) reported significantly higher intensities of reflection in comparison with the control group.

Contribution to learning

In the post-questionnaire participants evaluated each RT they used (76 opinions, due to the availability of the 3 RTs in group 2). 54\% of the collected answers mentioned RTs as contributors to learning.

Intention of reuse When asked whether they would make further use of the RTs in another learning context, 27\% answered "yes", 28\% "no" and 45\% "it depends". Only RT 3 (comment box) obtained a clear "yes" answer (50/\%). RT1 (yardstick) received the lowest "yes" ratings (16\%).

\section{Pros and cons}

The two corpuses of positive (83) and negative (80) comments on RTs (more than one comment per subject was allowed) were content analyzed in order to obtain categories that systematically summarize and reflect the data (Table 2 ).

\section{$<$ INSERT TABLE 3>}

Positive comments specified strong points of RTs (enhancement of reflection or monitoring, opportunities for comparison with others). The most often expressed criticism concerned usability aspects of the RT (eg. comment 30: "the comment box was hiding the text") or insufficient connection with instructional aspects (eg. comment 58: "the action indicator doesn't really say anything about your real learning progress"). A look inside each category showed a few concentrations of comments. For instance the category $\mathrm{n}^{\circ} 1$ comprised 20 comments ( $24 \%$ of all the positive comments) of which 10 came from G3 (G2: 6, G4: 2, G5: 2 ). A division by groups size (respectively $16,11,11,6)$ gave for each group the percentage of participants who produced a comment falling into this category. In this case, $91 \%(10 / 11)$ of participants in group 3 mentioned as a positive aspect that the RA they used provided opportunities for comparison. Only percentages higher than 50\% were indicated in table 3, along with the groups they owned to. (Despite the limited number of comments, at least in some categories, the percentages were given because they might prompt further enquiries about specific effects of certain RTs).

\section{Awareness of opportunities for reflection}

Data relating to awareness of reflection affordances came from the request: "We offered, in this online course, opportunities for reflection. Give as many of them you have noticed". Clearly, in treatment groups the awareness of available reflection opportunities was much higher: all treatment groups reported between 42 and 50\% more RTs than the control group. But the number of opportunities was not exclusively attributed to the presence of RTs. Participants rightly reported alternative opportunities for reflection like "control questions", 
"examples", "instructions before the start", "warning before taking the test", "text accessible". Deprived of structured RTs, the control group nevertheless pinpointed reflection opportunities in the course, though not to a large extent. In contrast, subjects in group 2 (all RTs condition) assimilated in a large proportion (70\%) the opportunities for reflection to the offered RTs that seem, in this case, to give a face value to reflection.

\section{Discussion}

The results show a differentiated picture.

\section{Primary research questions}

With regard to the first primary question "do RTs embedded in a study task engaged learners in active reflection?", the large usage of the reflection affordances and the self-reported measures of claimed intensity of reflection pointed at a positive answer. However, if this reflection truly took place, it was not traceable from the data. Also, it turned out that the mandatory use of recurrent but very compact episodes of reflection did not produce significant effect on performance and retention (second primary research question). To evaluate this result, 5 different explanations are now suggested, that future research will help to disentangle.

\section{Questioning RT}

One might propose: this kind of RT does not work. Compared to established techniques (portfolio, introspective dialogue, etc) aiming to generate reflection-on-action, these featherweight techniques targeting reflection-in-action do not measure up. At best, the study results disqualify RT as pointless, at worst as counterproductive to the performance.

\section{Questioning learners}

To preserve the RT, it is also possible to blame the learners by claiming that they underestimated the amount of effort needed to adequately apply the reflective introjections. The data suggests here possible nuances between high performers with a high level of prior meta-cognitive agility who discounted reflection affordances and low-performers who seemed to overlook them and failed to connect them well to the tasks. In all cases, a diligent but shallow use of the RTs would explain their lack of impact on performance.

Questioning the course

Authors (Bannert, Hildebrand, \& Mengelkamp, 2009; Hoffman \& Spatariu, 2008) suggest that amplifying reflection in non complex tasks is useless. In the study however, the contents of the course were certainly not straightforward: the performance tests showed that none of the test persons achieved high levels of mastery.

The length of the course can also be questioned. Two hours may be too short for various types of RTs to produce any differentiated effect on performance (Papadopoulos, Demetriadis, Stamelos, \& Tsoukalas, 2009; van den Boom, Paas, van Merrienboer, \& van Gog, 2004) and all the more so to suggest new reflective habits (Johnson \& Sherlock).

Questioning the notion of performance

The current study confined the measure of the learning performance to domain-specific knowledge. An extended version of performance, including meta-learning achievements, might give a different picture of RTs. The qualitative data pointed in that direction: a majority of users perceived RTs as useful to reflection and learning. (The influence of social desirability and Hawthorne effects might be suspected here. However, several qualitative questions converge across groups to produce a rather neat contrast between the subjective 
view and the absent or sometimes adverse effect on performance). In sum, these reflective artifacts that had no impact on performance were valued anyway, in relation to learning, by the largest part of the students (see similar discrepancies in Chiazzese et al. (2006) and in Thompson (2009)).

Questioning the setting

To explain why expected effects of RTs could not be traced in the students' mastery, some confounding conditions in the experimental setting may also be blamed, for instance the small size of the sample, and the absence of strict learning obligations, attracting voluntary learners that may be interested in reading through the course content but lack the intrinsic motivation of wanting to achieve high performances on the topic, possibly through a thorough use of RTs. When there is "enough learning" in the eye of a participant to an experiment remains an open question.

(One month after the end of the survey, participants were asked in a follow-up to select, among 10 plausible reasons, the one which best explained the absence of positive effect of the RTs on the performance. The 35 received answers showed a broad dispersion among the explanations: a) RTs offered episodes of reflection too small to be influential: $9 \%$, b) RTs were too repetitive and caused an over-prompting effect: $6 \%$,c) RTs were used superficially by participants: $11 \%$,d) RTs were useless for meta-cognitively agile participants: $3 \%$, e) RTs were useless for too easy task and content: $11 \%, \mathrm{f}$ ) RTs trained reflective habits impossible to install in a 2-hour course: $17 \%, \mathrm{~g}$ ) RTs increased the cognitive load: 3\%, h) RTs created confusion in the course between a performance and a learning orientation: $11 \%$, i) RTs broke the learning flow: $23 \%$,j) RTs trained skills that the test could not capture: $6 \%$. The relative contribution of a single treatment group to any of these percentages never exceeded $40 \%$ ).

\section{Secondary research questions}

The type and the number of offered reflection triggers did not make any difference regarding performance and regarding the "reflective flavor" they instilled in the course. This suggests that if RTs were effective, then any reflection trigger would do. The analysis of logs exhibited that this instant reflection is not time-consuming. The qualitative data backed this observation: the time needed for reflection was seldom mentioned as a hindrance. The short time needed to enact reflection affordances may have accounted for their rather high level of use. But this possible strength may easily turn into a weakness since the impact of such quick insights couldn't be traced in students' mastery. (It can also be noticed that the comment box, viz. the most time-consuming RT when properly completed, was offered in the group where the highest level of drop-outs was observed). If this study provided some indications that RTs might stimulate students' reflection in a cost-effective manner, the return that may be expected from such compact opportunities is still to be investigated.

\section{Recommendations for future research}

It is recommended that further empirical studies try to document the nature of the thoughts and of the learning context induced by RTs. It is also recommended that research on explicit reflection affordances interspersed with learning inspects its connections to:

a) Schön's model of reflection: does RTs invoke a standard reflection-in-action, as characterized by Schön as an immediate reflective response to a puzzling event in the practice. It seems that, while sharing some attributes of this type of reflection (on-thespot, amplified and explicit reflection), RT bear on a continuous awareness and appraisal of the act of learning itself more than on problem-solving flashlight insights. 
b) cognitive load theory (Sweller, 1994): in what circumstances does a RT convey intrinsic, germane or extraneous load? And for whom?

c) flow theory (Csikszentmihalyi, 1990): is there any possible value for a "flow breakers" as RTs? for whom are they helpful or disruptive?

\section{Conclusion}

How to encourage valuable reflection by learners, in a cost-effective manner, in the moment of learning? This study explored the provision of reflection triggers as one possibility. This first approach offers indications that: 1) in a quasi formal learning context, RTs were used as requested, 2) the use of RTs induced the feeling of a higher intensity of reflection, 3) RTs did not enhance exam performance, 4) despite this lack of effect on performance, a fair proportion of participants qualified RTs as contributors to learning 5) the use of RTs did not significantly extend the time spent on the course, 6) RTs instilled a higher awareness of the reflective approach applied to the course irrespective of the type and the number of RTs.

At this point of the inquiry, it remains uneasy to provide sound principles regarding RTs. Practitioners who would consider using such reflection affordances in a formal learning activity system should first evaluate against their audience and learning goals the relevance of giving a face value to reflection instead of assuming that this reflection will occur.

Overall, the findings of this study need to be considered with caution due to the small size of the sample. Observations and outcomes are useful as pilot research to inform the design of full-fledged experiments that employ larger samples and refined methodologies.

\section{Acknowledgments}

The authors feel obliged to Dr. Jakob Nielsen who gave permission for using his usability columns (www.useit.com) for the course. Gratitude also goes to Dr. Christian Glahn and Steinn Sigurdarson, who contributed to the technical development of the RTs.

\section{References}

Bannert, M., Hildebrand, M., \& Mengelkamp, C. (2009). Effects of a metacognitive support device in learning environments. Computers in Human Behavior, 25(4), 829-835.

Boud, D., Keogh, R., \& Walker, D. (1985). Reflection: turning experience into learning. London: Kogan Page.

Brockbank, A., \& McGill, I. (1998). Facilitating Reflective Learning in Higher Education. Buckingham: The Society for Research into Higher Education and Open University Press.

Brown, K. \& Ryan, R. (2003). The benefits of being present: The role of mindfulness in psychological well-being. Journal of Personality and Social Psychology, 84, 822-848.

Butler, D. L., \& Winne, P.H. (1995). Feedback and self-regulated learning: A theoretical synthesis. Review of Educational Research, 65, 245-281.

Cacioppo, J., \& Petty, R. (1982). The need for cognition. Journal of personality and social psychology, 42(1), 116-131.

Chi, M., De Leeuw, N., Chiu, M.-H., \& Lavancher, C. (1994). Eliciting self-explanations improves understanding. Cognitive Science, 18(3), 439-477.

Chiazzese, G., Ottaviano, S., Merlo, G., Chiari, A., Allegra, M., \& Seta, L. (2006). Surfing hypertexts with a metacognition tool. Informatica, 30, 439-445.

Csikszentmihalyi, M. (1990). Flow: The Psychology of Optimal Experience. New York: Harper and Row.

EuropeanCommission. (2006). Proposal for a recommendation of the European Parliament and of the Council on key competences for lifelong learning - COM(2005)548 final. 
Brussels: European Commission. URL

http://ec.europa.eu/education/policies/2010/doc/keyrec_en.pdf

Glahn, C., Specht, M., \& Koper, R. (2007). Smart indicators on learning interactions. In E. Duval, R. Klamma \& M. Wolpers Ed.(s), EC-TEL 2007 LNCS 4753 (pp. 56-70).

Berlin, Heidelberg: Springer.

Hattie, J. (2008). Visible Learning: A Synthesis of over 800 Meta-Analyses Relating to Achievement. London: Routledge.

Hoffman, B., \& Spatariu, A. (2008). The influence of self-efficacy and metacognitive prompting on math problem-solving efficiency. Contemporary Educational Psychology, 33(4), 875-893.

Johnson, M., \& Sherlock, D. (2008). Personal Transparency and self-analytic tools for online Habits. In Koper, R, Stefanov, K, \& Dicheva, D. Ed(s), Stimulating Personal Development and Knowledge Sharing. Proceedings of theTENCompetence International Workshop, Sofia, Bulgaria, 30-31 October 2008 (pp. 30-38) URL http://dspace.learningnetworks.org/handle/1820/1961

Marzano, R. J. (1998). A theory-based meta-analysis of research on instruction. Aurora, CO: Mid-continent Regional Educational Laboratory.

Moon. J. (1999). Learning Journals: A handbook for Academics, Students and Professional Development. Kogan Page, London.

Nielsen, J. (2010). Jakob Nielsen's Website. Retrieved online 01-03-2011 at: http://www.useit.com

Papadopoulos, P., Demetriadis, S., Stamelos, I., \& Tsoukalas, I. (2009). Prompting students' context-generating cognitive activity in ill-structured domains: does the prompting mode affect learning?. Educational Technology Research and Development, 57(2), 193-210.

Schön, D. (1983). The Reflective Practitioner: How professionals think in action. London: Temple Smith.

Schraw, G., \& Dennison, R. (1994). Assessing metacognitive awareness. Contemporary Educational Psychology, 19, 460-475.

Sweller, J. (1994). Cognitive Load Theory, learning difficulty, and instructional design. Learning and Instruction, 4, 295-312.

Taylor, P., \& Maor, D. (2000). Assessing the efficacy of online teaching with the Constructivist On-Line Learning Environment Survey. In Herrmann, A., \& Kulski, M. Ed.(s), Flexible Futures in Tertiary Teaching. Proceedings of the 9th Annual Teaching Learning Forum, 2-4 February 2000. Perth: Curtin University of Technology. URL http://lsn.curtin.edu.au/tlf/tlf2000/taylor.html

Thompson, C. (2009). Metacognitive Strategies of Teaching and Learning in Introductory Psychology Classes. Paper presented at the 3rd National Conference on Innovations in the Scholarship of Teaching and Learning at Liberal Arts Colleges. URL http://www.wabash.edu/sotl/docs/3 Thompsom IIB Paper.pdf

Van den Boom, G., Paas, F., van Merrienboer, J., \& van Gog, T. (2004). Reflection prompts and tutor feedback in a Web-based learning environment: Effects on students' selfregulated learning competence. Computers in Human Behavior, 20, 551-567.

Verpoorten, D., Westera, W., \& Specht, M. (2010). Reflection amplifiers in online courses: a classification framework. Journal of Interactive Learning Research, 21(4).

Verpoorten, D., Westera, W., \& Specht, M. (2011). Infusing reflective practice in eLearning courses - Can widgets help?. International Journal of Technology Enhanced Learning, 3(1), 93-109.

Wang, M., Haertel, G., \& Walberg, H. (1990). What Influences Learning? A Content Analysis of Review Literature. Journal of Educational Research, 84, 30-43. 
Watkins, C. (2001). Learning about Learning Enhances Performance. London: Institute of Education, University of London.

\section{LIST OF FIGURES AND TABLES}

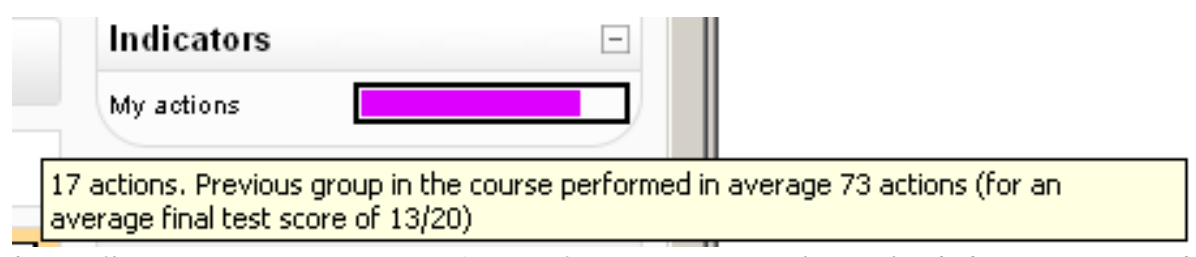

Figure 1: The reflection trigger (type 1) confronts personal tracked data to a yardstick (image taken from the treatment "All RTs")

\section{Rate your mastery of this page Show history of my ratings}

Rate your mastery of this page Hide history of my ratings

\section{5:53:16, August 31st 2010} 5 out of 5

15:49:57, August 31st 2010,Cs 4 out of 5

b

Figure 2: The reflection trigger (type 2) calls for a rating of mastery

Table 1: Overview of the 5 treatments, with offered reflection trigger(s)

\begin{tabular}{|c|c|c|c|c|}
\hline \multirow[t]{2}{*}{ Treatments } & \multicolumn{3}{|c|}{ Reflection trigger(s) offered } & Usable sample \\
\hline & $\begin{array}{c}\text { Compare } \\
\text { with } \\
\text { yardstick } \\
\text { (RT1) }\end{array}$ & $\begin{array}{c}\text { Rate your } \\
\text { mastery } \\
\text { of this page } \\
\text { (RT2) }\end{array}$ & $\begin{array}{c}\text { Write on the } \\
\text { content } \\
\text { (RT3) }\end{array}$ & \\
\hline $\begin{array}{l}\text { Group } 1 \text { (control): no } \\
\text { reflection trigger }\end{array}$ & 一 & - & 一 & $\mathrm{n}=10$ \\
\hline $\begin{array}{l}\text { Group } 2 \text { - all RTs } \\
\text { provided }\end{array}$ & $\mathbf{X}$ & $\mathbf{X}$ & $\mathbf{X}$ & $\mathrm{n}=16$ \\
\hline $\begin{array}{l}\text { Group } 3-\mathrm{RT} \text { type } 1 \\
\text { provided (yardstick) }\end{array}$ & $\mathbf{X}$ & - & - & $\mathrm{n}=11$ \\
\hline $\begin{array}{l}\text { Group } 4-\mathrm{RT} \text { type } 2 \\
\text { provided (rating) }\end{array}$ & - & $\mathbf{X}$ & - & $\mathrm{n}=11$ \\
\hline $\begin{array}{l}\text { Group } 5 \text { - RT type } 3 \\
\text { provided (comment box) }\end{array}$ & - & - & $\mathbf{X}$ & $n=6$ \\
\hline
\end{tabular}


Table 2: Results for the final test and for the retention test

\begin{tabular}{cccccc}
\hline Treatments & Mean Final Test & SD Final Test & Mean Retention Test & SD Retention test & $\mathrm{N}$ \\
\hline 1 & 13,4 & 5 & 3,17 & 1,6 & 10 \\
2 & 12,1 & 2,4 & 2,91 & 2,31 & 16 \\
3 & 12,3 & 4,5 & 2,73 & 2,95 & 11 \\
4 & 12 & 2,3 & 2,36 & 3,41 & 11 \\
5 & 12,8 & 2,7 & 2,93 & 3,91 & 6 \\
\hline
\end{tabular}

Table 3: Frequencies for categories of positive and negative comments on reflection triggers

\begin{tabular}{|c|c|c|c|}
\hline Positive Answer category & Frequency & Negative Answer category & Frequency \\
\hline $\begin{array}{l}\text { 1. RTs provide opportunities for } \\
\text { comparison with others }\end{array}$ & $\begin{array}{c}24 \% \\
(\mathrm{G} 3: 91 \%)\end{array}$ & $\begin{array}{l}\text { 1. Criticism on RTs' } \\
\text { usability }\end{array}$ & $\begin{array}{c}28.5 \% \\
(G 4: 52 \%)\end{array}$ \\
\hline 2. RTs enhance reflection & $\begin{array}{c}20.5 \% \\
(\mathrm{G} 4: 66 \%)\end{array}$ & $\begin{array}{l}\text { 2. Criticism on RTs' } \\
\text { didactics }\end{array}$ & $25 \%$ \\
\hline 3. RTs enhance monitoring & $17 \%$ & $\begin{array}{l}\text { 3. Criticism on RTs' } \\
\text { semantics }\end{array}$ & $19 \%$ \\
\hline 4. RTs are usable & $8 \%$ & $\begin{array}{l}\text { 4. RTs are } \\
\text { compulsory }\end{array}$ & $\begin{array}{c}10 \% \\
(\mathrm{G} 5: 66 \%)\end{array}$ \\
\hline 5. RTs make learning visible & $\begin{array}{c}6 \% \\
(\mathrm{G} 5: 76 \%)\end{array}$ & 5. RTs are useless & $6 \%$ \\
\hline 6. RTs enhance attention & $6 \%$ & 6. RTs are distractors & $4 \%$ \\
\hline $\begin{array}{l}\text { 7. RTs enhance mental } \\
\text { modelling of the learning } \\
\text { situation }\end{array}$ & $6 \%$ & 7. RTs take time & $4 \%$ \\
\hline 8. RTs are good for motivation & $5 \%$ & $\begin{array}{l}\text { 8. RTs allow a shallow } \\
\text { use }\end{array}$ & $2.5 \%$ \\
\hline $\begin{array}{l}\text { 9. RTs are good for } \\
\text { personalisation }\end{array}$ & $2.5 \%$ & 9. RTs seem silly & $1 \%$ \\
\hline $\begin{array}{l}\text { 10. RTs are good for active } \\
\text { commitment to the task }\end{array}$ & $2.5 \%$ & & \\
\hline \multirow{2}{*}{$\begin{array}{l}\text { 11. RTs are good for learning to } \\
\text { learn }\end{array}$} & $2.5 \%$ & & \\
\hline & $100 \%$ & & $100 \%$ \\
\hline
\end{tabular}

